\title{
Testing and Demonstration of Small Scale Tomato Processing Technologies in Amhara Region Fogera District
}

Ayalew Demissew*, Ayenew Meresa and Mehiret Mulugeta

Amhara Regional Agricultural Research Institute, Bahir Dar Food Science and Postharvest Handling Research Center, Bahir Dar, Ethiopia

\begin{abstract}
Tomato (Solanum lycopersicum) is a typically red edible fruit and belongs to the Nightshade family (Solanaceae). The shelf life of fresh tomato was short period and postharvest loss in Ethiopia is around $30 \%$ to $40 \%$. Proper postharvest handling and storage methods are essential for maintaining acceptable quality and extending the shelf life. In this study different small-scale tomato processing technologies (jam, sauce and pasteurized juice) had been tested and demonstrated in Fogera district. The shelf life of the product was evaluated by physical method and the product shelf stability was also found remarkable.
\end{abstract}

Keywords: Tomato; Jam; Sauce; Shelf life

\section{Introduction}

Tomato (Solanum lycopersicum) is a typically red edible fruit and belongs to the Nightshade family (Solanaceae) except for the tiny current tomato. This family is the most variable of all crop species in terms of agricultural utility and the third economically most important crop family, exceeded only by grasses and legumes and the most valuable in terms of vegetable crops. Nigeria is second largest producer of tomato in Africa next Egypt. Tomatoes are highly perishable and very susceptible to mechanical damage with poor handling and transportation system. In addition to mechanical damage at high temperatures, fruits and vegetables transpire and respire which leads to spoilage. Due to this problem, the produce should be harvested in the morning to ensure that they are at the coolest possible temperature during the delay between harvest and initial cooling.

Tomatoes have a very short market life if harvested fully ripe. Mature-green or breaker stage fruit may last for several weeks. Fresh vegetables postharvest loss occurs along chain of supply from the producer to the consumer. Losses occur at the stages of sorting, packaging, storage, transport and marketing stages of the life the fresh horticultural produce. Tomato fruit are very delicate and can quickly be injured by rough harvesting and handling practices. The fruit is also damaged by holding at either too low or too high a temperature. Proper postharvest handling and storage methods are essential for maintaining acceptable quality and extending the market life. Among vegetables, tomatoes and tomato products are rich sources of carotenoids and lycopene is the most abundant pigment (60\% to 64\%) which is responsible for red color [1].

Tomatoes in Ethiopia are produced mainly in the northern and central rift valley areas. In recent years, commercial tomato production has significantly expanded since national agricultural strategies began favoring high value cash crops. The total area of land estimated to be covered by tomato farms in 2011/12 is 7,255 ha with an estimated yield of 81,970 metric tons (11.3 MT/ha) [2]. But In developing countries, there is lack of storage facilities on-farm or at wholesale or retail markets and lack of ventilation and cooling systems. Over-loading of cold stores (where available) including placing warm produce into the cold room, stacking produce too high (beyond container strength) and the practice of mixing produce with others with different temperature. When tomato is stored at $10^{\circ} \mathrm{C}$ with the optimum humidity of about $80 \%$, green tomatoes can be stored for 16-24 weeks [3].

Although tomato is a highly perishable crop, the rate and extent of spoilage depends on several factors and that, to overcome this problem calls for the need to develop simple, cost-effective, and easily adaptable preservation and processing techniques. Tomatoes can be processed into many forms to be consumed instantly or preserved for future use. The data on physicochemical properties of agro-food materials are valuable because they are needed as input to models, predicting the quality and product behavior. The correlation between laboratory test processes and the physicochemical qualities of tomato varieties will contribute to develop an optimal solution for processing and product quality. Tomato postharvest loss in Ethiopia is high which reaches around $30 \%$ to $40 \%$ due to absence small scale processing and preservation technologies which are cost affordable and technically feasible for small holder farmers and small-scale enterprises. Tomato is one of the major vegetable crops being highly perishable in its nature. It creates glut during it short production season and become very scarce and expensive during its off season, its short life and absence of processing and preservation leads to loss of revenue to the farmers. So, in this study small scale tomato processing technologies were tested and demonstrated at Fogera district on tomato potential farmers and district small scale food processing entrepreneurs.

\section{General objective of the study}

Minimizing post-harvest loss and availability of essential vegetables using small scale processing technologies.

\section{Specific objectives}

- To characterize important physicochemical properties of district tomato cultivars.

- To facilitate tomato adoption and utilization in rural areas by reducing postharvest loss.

*Corresponding author: Ayalew Demissew, Amhara Regional Agricultural Research Institute, Bahir Dar Food Science and Postharvest Handling Research Center, P.O. box 794, Bahir Dar, Ethiopia, Tel: +251912604705; E-mail: ayalewdemissew@yahoo.com

Received May 15, 2017; Accepted June 05, 2017; Published June 12, 2017

Citation: Demissew A, Meresa A, Mulugeta M (2017) Testing and Demonstration of Small Scale Tomato Processing Technologies in Amhara Region Fogera District. J Food Process Technol 8: 678. doi: 10.4172/2157-7110.1000678

Copyright: @ 2017 Demissew A, et al. This is an open-access article distributed under the terms of the Creative Commons Attribution License, which permits unrestricted use, distribution, and reproduction in any medium, provided the original author and source are credited. 
- To introduce small scale tomato processing technologies in rural women so that they can generate additional income and enhance their livelihood.

\section{Materials and Methods}

\section{Sample collection and preparation}

Tomato sample was bought from farmers at Fogera district. Then the fruit was sorted, cleaned with potable water, peeled, and pulped in electric homogenizer. The $\mathrm{pH}$, titrable acidity, shape, moisture and total soluble solid content of the fruit pulps were determined using AOAC method [4].

\section{Tomato jams processing}

In tomato jam making process amount of pectin in the formulated batch was determined from laboratory trial production and observation of product consistency. So, the ratio of ingredients was (one-liter tomato juice, $740 \mathrm{gm}$ sugar, $50 \mathrm{ml}$ pectin solution and $15 \mathrm{ml}$ citric acid). Tomato juice boiled with the addition of sugar and when the mixture started boiling pectin was added. Finally, citric added and the mixture allowed to boil until the total soluble solid (TSS) content of the jam reach $68^{\circ}$ Brix. The jam was then hot filled in clean sterilized glass jars and then the product was pasteurized in pressure cooker. Lastly the jars were sealed by hot water bath canning system and stored in ambient temperature for shelf life examination.

\section{Tomato sauce processing}

Ingredients of tomato sauce (one-liter tomato juice, 15 gm ginger and $30 \mathrm{gm}$ salt). Tomato juice was boiled with spice bag containing ginger to $30^{\circ}$ Brix. Finally, salt was added and the sauce was then hot filled in clean sterilized glass jars and then the product was pasteurized in pressure cooker. Lastly the jars were sealed by hot water bath canning system and stored in ambient temperature for shelf life examination.

\section{Tomato pasteurized juice processing}

Ingredients of tomato pasteurized juices which were formulated in laboratory trial (one-liter tomato juice, $75 \mathrm{gm}$ ginger, $5 \mathrm{~g}$ salt and 60 $\mathrm{ml}$ citric acid). Tomato juice was boiled with sugar until the mixture reaches $80^{\circ} \mathrm{C}$. Finally, salt and citric acid was added boiled for 20 minutes and hot filled in clean sterilized glass jars and then the product was pasteurized in pressure cooker. Lastly the jars were sealed by hot water bath canning system and stored in ambient temperature for shelf life examination.

\section{Shelf life examination}

The shelf life the products were determined by physical method. The products were stored in dry and cool place. Shelf life of products was evaluated using sensory and microbial analysis periodically in each three months periodically

\section{Microbial analysis}

One-gram sample of paste was transferred in $99 \mathrm{ml}$ of distilled water and the mixture was homogenized with continuous shaking for several minutes. Then, $1 \mathrm{ml}$ of the sample solution was diluted in another tube with $9 \mathrm{ml}$ distilled water. The total viable count per gram of sample was carried out following the method of American Public Health Association [5].

\section{Sensory analysis}

Ten trained panelists of the center were used for sensory evaluation

\begin{tabular}{|c|c|}
\hline Property & Values \\
\hline Titrable acidity & $0.54 \%$ \\
\hline PH & 4.5 \\
\hline Shape & Elongated \\
\hline Moisture content & $87.34 \%$ \\
\hline Dry mater content & $12.66 \%$ \\
\hline TSS & $4.6^{\circ} \mathrm{Brix}$ \\
\hline
\end{tabular}

Table 1: Some physicochemical properties.

\begin{tabular}{|c|c|c|c|c|}
\hline \multirow{2}{*}{ Products } & \multicolumn{4}{|c|}{ Aerobic Count Plate (CFU/g) } \\
\cline { 2 - 5 } & $\begin{array}{c}\text { First 3 } \\
\text { months }\end{array}$ & $\begin{array}{c}\text { Second 3 } \\
\text { months }\end{array}$ & $\begin{array}{c}\text { Third 3 } \\
\text { months }\end{array}$ & $\begin{array}{c}\text { Fourth 3 } \\
\text { months }\end{array}$ \\
\hline Jam & $2 \times 10^{3}$ & $4 \times 10^{3}$ & $4 \times 10^{3}$ & $2 \times 10^{3}$ \\
\hline Juice & $6 \times 10^{3}$ & $10^{4}$ & $1.2 \times 10^{5}$ & $2 \times 10^{5}$ \\
\hline Sauce & $4 \times 10^{3}$ & $8 \times 10^{3}$ & $1.2 \times 10^{3}$ & $5 \times 10^{4}$ \\
\hline
\end{tabular}

Table 2: Bacterial count of tomato products.

\begin{tabular}{|c|c|c|c|}
\hline Tomato products & Colour & Taste/flavor & $\begin{array}{c}\text { Overall } \\
\text { acceptability }\end{array}$ \\
\hline Jam & $6.88 \pm 0.22$ & $7.34 \pm 0.02$ & $6.8 \pm 0.08$ \\
\hline Sauce & $7.44 \pm 0.08$ & $6.86 \pm 0.11$ & $7.4 \pm 0.09$ \\
\hline Pasteurized juice & $7.8 \pm 0.03$ & $7.45 \pm 0.9$ & $7.8 \pm 0.28$ \\
\hline
\end{tabular}

Table 3: Summarized sensory results of products.

of products. Major sensory attributes evaluated were taste/ flavor, color and overall acceptability according to 9-point Hedonic scale. Sensory evaluations of the products were conducted until the end of shelf life of the products periodically.

\section{Result and Discussion}

\section{Physicochemical properties of tomato sample}

Physicochemical properties of tomato sample were shown in the Table 1 below. The titer-able acidity of tomato was found $0.5 \%$ which was a good agreement with the report by Workneh et al. [6] while the shape of tomato was elongated. The moisture and dry matter content were $87.34 \%$ and $12.66 \%$ respectively which was different from a report by Sua' rez et al. [7]. The total soluble solid of tomato was found $4.6^{\circ} \mathrm{Brix}$ which was also reported by Sobowale et al. [8].

\section{Shelf life of the products}

Microbial analysis: The bacterial count of processed tomato food product is shown in Table 2 below. Bacteria, yeasts and moulds are normally found in processed foods and cause the spoilage due to their ability to multiply in the foods. Bacteria cause most food spoilage most rapidly due to their short generation times compared with fungi. Food spoilage is the alteration of the quality characteristics (such as appearance, taste, texture, odour) due to enzymatic and microbial attacks of food thereby making the food unacceptable. These changes are not always microbiological in origin but physical/chilling damage make the food become predisposed to microbial spoilage [9]. As it is observed in the Table 2 below tomato jam could stay one year while tomato sauce stayed for nine months safely. But the shelf life of tomato pasteurized juice was only six months. During the shelf life period of tomato products, the bacterial count found was below spoilage detection level [10].

Sensory analysis: Sensory results of processed tomato products are shown in Table 3 below. The sensory results in the table only include the result of the product where the product shelf life is viable. Visual characteristics are very important for quality differentiation. Therefore, many studies on storage life of processed vegetables are including 
sensory evaluations in their experiments, have focused on visual quality or overall quality, based on appearance, although also other sensory factors can play a role in the sensory shelf life. Texture degradation is observed as a sensory characteristic when a relatively large part of the textural structure becomes degraded. This is in contrast with odour or visual defects, which can originate from some small areas of the tissue. In many cases, the micro-organisms responsible for the presence of offodours and off-flavours have not been fully identified [11].

Food safety is a major focus in Food Microbiology and it describes handling, preparation/ processing and storage of food in ways that prevent food-borne illnesses and food poisoning. In developed countries, there are intricate and well-articulated standards for monitoring food safety but in many less developed countries (including Nigeria), these measures are at the formative/review stages. Questions concerning the relevance of microbiological standards in the country had earlier been raised [12]. Along the shelf life of processed tomato products (jam one year, sauce nine month and pasteurized juice six month) the sensory analysis result of showed a remarkable result.

\section{Conclusion and Recommendations}

The postharvest loss of tomato can be reduced by popularizing these small-scale processing technologies in Fogera district. The shelf life of tomato jam produced by using the is procedure has shelf life of one year while the shelf life of tomato pasteurized juice was found to be 6 months only while tomato sauce stayed nine months. Preserving tomato products by processing at small scale level to this extent was great achievement where tomato postharvest loss is about $40 \%$ in the production season in the area. Small scale tomato processing technologies shall be further popularized by governmental or nongovernmental organizations.

\section{References}

1. Georgé S, Tourniaire F, Gautier H, Goupy P, Rock E, et al. (2011) Changes in the contents of carotenoids, phenolic compounds and vitamin $\mathrm{C}$ during technical processing and lyophilization of red and yellow tomatoes. Food Chem 124: 1603-1611.

2. Tefera A, Tefera $T$ (2013) Tomato production in Ethiopia challenged by pest USDA Foreign Agricultural Service, Addis Ababa, Ethiopia.

3. Dauthy ME (2009) FAO investment centre division. Fruit and vegetable processing, Rome, Italy.

4. AOAC (1984) Official method of analysis. Association of official analytical chemists, Washington DC, USA.

5. APHA (1967) Recommended method for the microbiological examination of food. American Public Health Association, New York, USA.

6. Workneh TS, Tigist A, Woldetsadik K (2012) Effects of variety on yield, physical properties and storability of tomato under ambient conditions. Africa J Agric Res 7: 6005-6015.

7. Sua'rez MH, Rodrı'guez EM, Romero CD (2007) Chemical composition of tomato (Lycopersicon esculentum) from Tenerife, the Canary Islands. J Food Chem 106: 1046-1056.

8. Sobowale SS, Olatidoye OP, Odunmbaku LA, Raji OH (2012) A comparative study on physicochemical and rheological properties of imported tomato paste in Nigeria. Sustainable agriculture research, Canadian Center of Science and Education.

9. Snowdon AL (1990) A colour atlas of post-harvest diseases and disorders of fruits and vegetables. Wolfe Scientific Ltd, Barcelona, Spain.

10. Ray B, Bhunia A (2008) Fundamental food microbiology. CRC Press, Boca Raton, Florida.

11. Whitfield FB (1998) Microbiology of food taints. Int J Food Sci Technol 33: 31-51.

12. Ibe SN (2008) Microbiological standards for foods: Are they relevant in Nigeria? University of Port Harcourt inaugural lecture series (Inaugural lecture no. 60), Nigeria. 